\title{
APPLICATION OF CHEMICAL METHODS TO THE SOLID WASTE MANAGEMENT
}

\author{
C. P. Bulimaga \\ Institute of Ecology and Geography ASM, Str Academiei, 1, Republic of Moldova \\ cbulimaga@yahoo.com,tel+37322723544,fax+37322211134
}

\begin{abstract}
The present article is a synthesis analysis of application of chemical methods for the development of technologies of hazardous waste management. Here are offered some technologies of neutralization of the waste containing hexacyanofferates, galvanic wastes and those with contain of vanadium, which are collected at Power Thermoelectric Plants.
\end{abstract}

Keywords: waste, hexacyanoferrates, galvanic wastes, waste from Heat and Power Plants, environmental assessment

\section{Introduction}

A large number of modifications has happened in the world due to the technical and scientific progress and as a result of manufacturing methods modernization. Among these changes is the creation of an enormous industrial and agricultural potential, transport development, unlimited use of natural resources, etc. A massive industrialization during almost two last centuries has contributed to resource depletion as well as favored accumulation of waste with a strong negative impact on the environment.

In the given context, in 1991, participants of the Dobrosh Castle conference, the Czech Republic[1] that represented 50 European states, clearly recognized a large number of essential factors that influence environment: climate change, ozone layer deterioration, acid rains, hazards, urban stress and chemical risk among the others. This subject was discussed by UNEP as well, that approved "Program of the United Nations for the environment at the end of the second millennium" [2]

The wastes present an important factor of environmental pollution. Many concepts, strategies, procedures and methods of environmental protection and health security had been elaborated since the negative impact of waste was found out. However, those didn't avert discords of economic development and nature, but they improved partly the enlargement of contradiction. Negative environmental effects at the regional and global level as well as the environmental conditions at the local level are keeping on deterioration.

One of the major directions of waste management and environmental protection is the reduction of the waste amount based on the improving of the technologies and management. According to data of the Global conference in Strasbourg, 1992 [3] the total amount of waste in the OECD countries in 1990 made up more than 2 billions tons, but in 1993 this exceeded up to 2, 446 billions tone from which the domestic waste amount of up to 5\%, industrial waste up to $13,5 \%$, agricultural up to $28,6 \%$, ore waste -14 up to $7 \%$, waste from Power Plants - up to $1,1 \%$, silt (mud) of waste water treatment - up to $25,3 \%$, building waste - up to $10,6 \%$. [4]

According to the data [5], the amount of domestic solid waste (DSW) in Europe is in the keen of growing, coming up to 306 million tons or $415 \mathrm{~kg}$ year per capita. Amount of DSW varies from country to country and makes up to 685 $\mathrm{kg} /$ year per capita in Iceland and $105 \mathrm{~kg} /$ year per capita in Uzbekistan. (tab.1). DSW come up to 14\% of total amount in Western Europe and 5\% in Eastern Europe. The basic procedure of solid waste management is neutralization by burial ground disposal. Index of waste accumulation grows annually in the most of the countries, the index of waste treatment and management keeping low. The biggest amount of waste generation (1,14 t kg/year per capita) is in the U.S. The similar tendency is observed in other countries as well. The highest environmental impact is accounted for by waste from industry (ISW). The amount of DSW and ISW in the countries of the European Union and Moldova are in the tab.1.

Table 1

Amount of waste generated in the countries of the EU and Moldova per capita in the year 2003 [6]

\begin{tabular}{lccc}
\hline Country & $\begin{array}{c}\text { Total, waste } \\
\text { kg/per capita } *\end{array}$ & Municipal waste, $\%$ & $\begin{array}{c}\text { Industrial waste, } \\
\text { \% }\end{array}$ \\
\hline Belgium & 1391 & 25,3 & 74,7 \\
\hline Denmark & 1058 & 51,0 & 49,0 \\
\hline Germany & 1959 & 28,6 & 71,4 \\
\hline France & 1070 & 37,5 & 62,5 \\
\hline Ireland & 1235 & 34,8 & 65,2 \\
\hline
\end{tabular}




\begin{tabular}{lccc}
\hline Holland & 1132 & 48,8 & 51,2 \\
\hline Great Britain & 1664 & 35,5 & 64,5 \\
\hline Romania & 2079 & 17,31 & 82,90 \\
\hline Republic of Moldova** & 1700 & 3,8 & 96,2
\end{tabular}

*) Badea A., Apostol T, Mărculescu C, 2003[10]; **) Departament of Statistics ans Sociology of Moldova.

Anuarul Statistic al Republicii Moldova anul 2003. Chişinău, 2003, 704 p.

The industrial wastes play the most important role in the solid waste composition. In the European Union countries it comes up to (\%): Belgium 74,7; Germany 49,0; France 71,4; Ireland 65,2; Holland 51,2; Great Britain 64,5 and Romania 82,9, but in the Republic of Moldova 93-95\%. These data demonstrate that the ratio of industrial waste makes up from 51,2 (Holland) to $82,9 \%$ (Romania) but in Moldova the amount of solid waste is the biggest part in total amount. The dynamics of industrial waste generation in Moldova is presented in table 2.

Table 2

Amount of waste generated in Moldova in 2001-2005*

\begin{tabular}{lccccccccccc}
\hline $\begin{array}{l}\text { Type of } \\
\text { waste }\end{array}$ & $\mathbf{2 0 0 1}$ & \multicolumn{2}{c}{$\mathbf{2 0 0 2}$} & $\mathbf{2 0 0 3}$ & $\mathbf{2 0 0 4}$ & \multicolumn{2}{c}{$\mathbf{2 0 0 5}$} \\
\cline { 2 - 11 } & Thous. t & $\mathbf{\%}$ & Thous.t & $\mathbf{\%}$ & Thous. t & $\mathbf{\%}$ & Thous.t & \% & Thous.t & \% \\
\hline Industrial & 5963,3 & 98,4 & 5172,3 & 93.0 & 3579,2 & 96,2 & 4692,8 & 96,3 & 4140,0 & 95,9 \\
\hline Municipal & 97,7 & 1,6 & 391,7 & 7,0 & 140,8 & 3,8 & 180,2 & 3,7 & 178,8 & 4,1 \\
\hline Total & 6061,0 & 100 & 5564 & 100 & 3720 & 100 & 4873 & 100 & 4323 & 100 \\
\hline
\end{tabular}

*) Anuar. Calitatea factorilor de mediu şi activitatea Inspectoratului Ecologic de Stat. // Chişinău, 2001.

Departamentul Statisticii şi Sociologiei al Republicii Moldova. Anuarul Statistic al Republicii Moldova anul 2002 Chişinău: Tipografia S.A.”CRIO”, 2002. 525 p.; Departamentul Statisticii şi Sociologiei al Republicii Moldova. Anuarul Statistic al Republicii Moldova anul 2003. Chişinău, 2003, 704 p.; Starea mediului în Republica Moldova în anul 2004, Ministerul Ecologiei şi Resurselor Naturale al Republicii Moldova,123 p.; Starea mediului în Republica Moldova în anul 2005, Ministerul Ecologiei şi Resurselor Naturale al Republicii Moldova, 116 p.

According to the data from Table 2, the quantities of industrial waste during the mentioned period of time come to $98,4-93 \%$, that proves the necessity of their reuse.

Dynamics of waste generation and accumulation unambiguously demonstrates the reduced efficacy of waste management. This fact has strongly initiated a re-orientation in the frame of national strategy of waste management, leading towards activity of waste prevention and recycling. A diminution of DSW amount per capita is observed in Canada and Great Britain. Basically, DSW are generated and just saved in some opened areas that stipulates for the occupation of large zones and provokes the negative effect on the environment due to dangerous emissions and waste water formation. Thus waste generation remains an acute problem that seeks for a elaboration of new systems and technologies of solution. Dangerous environmental impact at regional and global scale, the deteriorated environmental situation keeps on worsening from year to year. This fact concerns Moldova, too.

There is a very critical situation in Moldova with the dangerous waste, such as: vine-making waste (6678 $t$ ), pesticides (POP-s) (more than $1678 \mathrm{t}$ ), vanadium contained waste (about $500 \mathrm{t}$ ), galvanic waste (more than $2000 \mathrm{t}$ ), mud from the water purification plant which provokes green house emissions (more than 600 thousands tons) [7]. This situation is an argument in the favor to investigate and to find solutions from the scientific point of view, connected with evaluation of waste chemical composition and adequate its management. The problem can be solved by non conventional way, what include both: the multivarious ecological waste investigations and the elaboration of chemical-technological methods of waste valorification.

In this context a conception of sustainable development plays an important role for natural resources conservation, because the industrial and agricultural waste are examined as a second source of row materials. The goal of this paper is to elaborate the procedures and technologies of valorification of some industrial waste generated at the factories from the R.M. 


\section{Waste generation}

\section{Hexacyanoferrate wastes}

In the last two decades as a result of development of vine-making branch in the RM similar with the other states from the CIS ( the Ukraine, Russia, Georgia, Armenia, Azerbaidjan and some countries from Europe and Est-Europe, such as Romania and Bulgaria) an essential quantity of dangerous waste is vine-making waste. In the period of 19941998 years the quantity of this waste was increased up to 7374 tones. Then, their quantity has decreased to 6622 tons in the 1999 year. The maximum quantity was registered in the period of the 2001year - $7463 \mathrm{t}$ (fig. 1). At present the quantity of the hexacyanofferarate waste is $6678 \mathrm{t}$ [9]. The vine-making waste in the Republic was increased from 3300 up to $7463 \mathrm{t}$, in the last 12 years the annual average quantity has the values of 5800-5900 $\mathrm{t}$ (fig.1).

The vine-making wastes are deposited in the territories of vine factories and can include from 10 up to $30 \%$ of sediments of vine-making waste. There are metallic and betony capacities and tanks for depositing these wastes. In the upper part of tank (capacity) is a liquid phase which consists from vine and the mixture of the gelatin destruction products and the fish glue, used as the flocculants for vine purification and precipitation of the colloidal suspension. Liquid phase ( $\mathrm{pH} 3-5)$ includes also the part of the ferrocyanide (vine-making waste) compounds and have a specific smell of the acetic acid and spoiled protein, in the bottom layers the ferrocyanide compounds are increased from 10 up to $60 \%$. For waste concentration can be used cylinder which contain a special adsorption (diatomit, silicium compounds and other substances) layer. As a result the homogeny viscose mixture is obtained. The liquid phase consists of $90 \%$ of bentonite, the vine residue and $5-10 \%$ of ferrocyanide.

There are the $\mathrm{Cu}^{2+}$ ions in the vine, as a result of the vineyard treatment with $\mathrm{CuSO}_{4}$ solution, as well as the $\mathrm{Fe}^{2+}$ and $\mathrm{Fe}^{3+}$ ions from the iron installation used for vine production. The presence of these ions has a negative influence on the vine quality. That is why hexacyanoferrate complex ion $\left[\mathrm{Fe}(\mathrm{CN})_{6}\right]^{4-}$ is used for its precipitation. The maximal admissible concentration of $\left[\mathrm{Fe}(\mathrm{CN})_{6}\right]^{4-}$ is $0,005 \mathrm{~g} / 1[10]$.

The oxidation of $\mathrm{Fe}$ in $\mathrm{Fe}^{2+}$ ion can be presented by chemical reaction:

$$
2 \mathrm{H}^{+}+\mathrm{Fe}^{0}=\mathrm{Fe}^{2+}+\mathrm{H}_{2}
$$

As a result of partial oxidation of $\mathrm{Fe}^{2+}$ the mixture of $\mathrm{Fe}^{2+}$ and $\mathrm{Fe}^{3+}$ is formed. The process of $\mathrm{Fe}^{2+}, \mathrm{Fe}^{3+}$ and $\mathrm{Cu}^{2+}$ ions neutralization with $\mathrm{K}_{4}\left[\mathrm{Fe}(\mathrm{CN})_{6}\right]$ is presented in (2) - (4).

$$
\begin{aligned}
& 2 \mathrm{Fe}^{2+}+\left[\mathrm{Fe}(\mathrm{CN})_{6}\right]^{4-}=\mathrm{Fe}_{2}\left[\mathrm{Fe}(\mathrm{CN})_{6}\right] \downarrow \\
& 4 \mathrm{Fe}^{3+}+3\left[\mathrm{Fe}(\mathrm{CN})_{6}\right]^{4-}=\mathrm{Fe}_{4}\left[\mathrm{Fe}(\mathrm{CN})_{6}\right]_{3} \downarrow \\
& 2 \mathrm{Cu}^{2+}+\left[\mathrm{Fe}(\mathrm{CN})_{6}\right]^{4-}=\mathrm{Cu}_{2}\left[\mathrm{Fe}(\mathrm{CN})_{6}\right] \downarrow
\end{aligned}
$$

A suspension of bentonite and fish clay is supplemented, too, to facilitate the sedimentation of these hexacyanoferrates. The vine waste remains after vine decantation and filtration. There is the colloidal yeast fraction, tartaric acid, vine residues in the waste, too. The content of hexacyanoferrates in the waste is 5-10\% $(50-100 \mathrm{~g} / \mathrm{kg})$ from the dry mass. Early the vine waste was liquidated by landfills disposal without some treatment. After 1980 this waste was accumulated at the factories of its, generation.

Tons

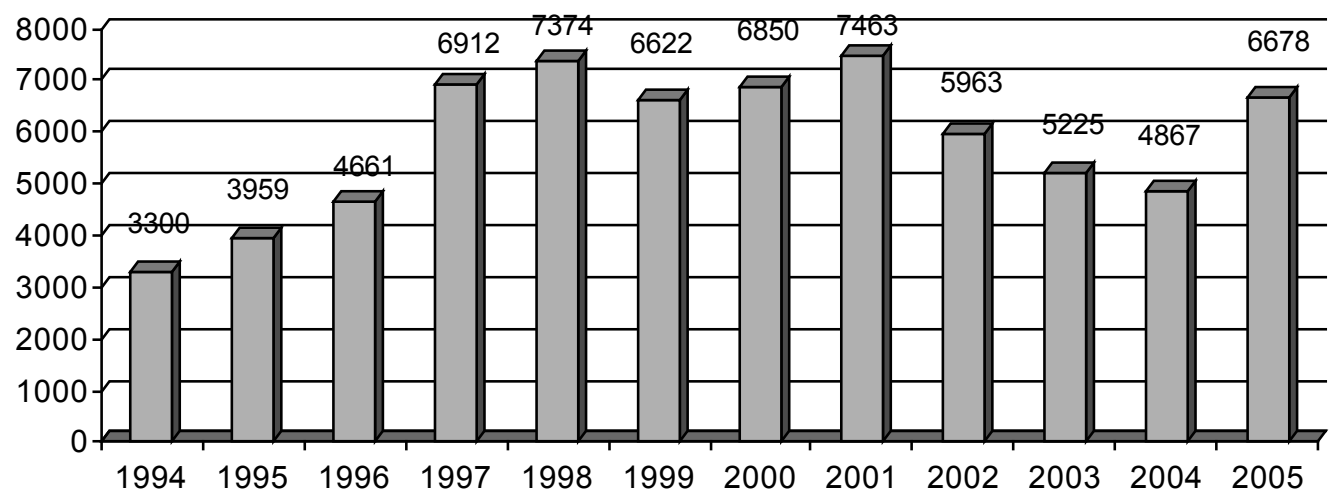

Fig. 1. The vine waste quantities deposited at the vine factories in RM

There are many procedures of hexacyanoferrate waste neutralization, such as chemical treatment by sedimentation, oxidation, catalytic methods and others [11-23]. 
For hexacyanoferrate waste deactivation by Covalev V., Covaleva O. [18] was proposed the filtration through the sawdust of tree mixed with coal dust and following incineration. The gas emissions were purified. The advantage of this method is the use of cheap and accessible materials, but the process is time consuming, and it is necessary to purify and to verify the gas emissions for exclusion of the air pollution. That caused the supplementary cost.

Another method is the treatment of hexacyanoferrate for the transformation of waste in the soluble state by alkali using, following a treatment by catolyt and oxidation with anolyt [19]. This technology is advantageous, but because the oxidation process is difficult to be realized (respecting of strong parameters regime such as concentration of oxidizer, $\mathrm{pH}$, a high temperature, etc.) and a high cost of reagent $\left(\mathrm{H}_{2} \mathrm{O}_{2}\right)$ is used.

Thus, the diverse methods of vine waste treatment have been elaborated [11-23], majority of them is interesting from the applicative point of view $[18,19]$, but its implementation for waste detoxcation at large scale has not been realized so far.

As a result of analysis of diverse technologies and of the possibilities of its implementation, we have drawn a conclusion that it is necessary to elaborate a new chemical procedure for hexacyanoferrate waste detoxcation which can be used exactly at the site of waste formation and disposal, using the installations from the vine factory and excluding the necessity of special has been modern installations with high costs.

\section{Galvanic waste}

The elaboration of technologies of valorification of diverse types of waste including galvanic waste with the high content of heavy metals is in the focus of great attention in the mondial practice of waste management.

The quantity of galvanic waste deposited at the "ALFA" factory the city of Chişinău at the end of the 2002 year was about 1000 tons, and these wastes were deposited in the special basin built according to the requirement.

With the dependence of the site of waste collection the $\mathrm{Cu}$ content was 15-35\% and more or less for other metals (AL, Cr, $\mathrm{Zn}, \mathrm{Fe}$ and other). The galvanic waste containing a large spectrum of metals, it could serve as rich second ores of color metals. A estimation has demonstrated that the treatment of 1000 tons of galvanic waste in order to obtain of cuprum and other metals valorification will contribute to the obtaining of 150-300 tons of metals and to the waste neutralization.

There are different methods for wastewater purification from heavy metals. Some authors proposed the waste water purification (the removal of heavy metals) by $\mathrm{Na}_{2} \mathrm{CO}_{3}$ solution treatment [24]. The deficiency of this method is an unsatisfactory grade of water purification and the great consumer of $\mathrm{Na}_{2} \mathrm{CO}_{3}$. The other procedures of wastewater galvanic purification [25] consist of the use of $3,0 \%$ of $\mathrm{Ca}(\mathrm{OH})_{2}$ for heavy metals precipitation. But this method doesn't provide the complete waste water purification either. Schegliuc and coauthors [26] proposed a procedure for the treatment of heavy metal containing wastewater with the use of iron (II) and iron (III) in the ratio of $\mathrm{Fe}$ (II) to $\mathrm{Fe}$ (III) for 1:2 gram-ion/1 and as well an addition of iron(II) $\geq 0,5$ gram-equivalent up to the content the of general heavy metals - 1 gram-equivalent, after that the introduction of alkali in the mixture by intensively mixing in the continuum or alternative electromagnetic field with the current strength no more than $1 \mathrm{~A} / \mathrm{m}^{2}$.

In the case of $\mathrm{Cr}(\mathrm{VI})$ containing wastewater it is necessary to respect a ratio of $\mathrm{Fe}(\mathrm{II})$ to $\mathrm{Cr}(\mathrm{III})$. It is established that 4,5 gram-ion $\mathrm{Fe}(\mathrm{II})$ to 1 gram-ion of $\mathrm{Cr}(\mathrm{VI})$ are optimal. This fact is necessary for formation of ferrites of heavy metals: $\mathrm{MeO} \circ \mathrm{FeO} ; \mathrm{MeO} \circ \mathrm{Fe}_{2} \mathrm{O}_{3}$.

Budilovscii and auth. [27] proposed the galvanic wastewater treatment with hydroxide of iron ( $\mathrm{pH} 8,0-8,5)$, but they involved the supplementary addition of $\mathrm{Al}$ (III) in the quantity of $2-10 \mathrm{mg} / \mathrm{l}$ for improving of nickel sedimentation, which creates the conditions of complete wastewater purification from nickel. The effective Al (III) and Ni (II) ions sedimentation is conditioned by the reaction of some chemical complex of aluminum and nickel ions and the aluminates ions formation (the mixt complexes of salts of $\mathrm{AL}$ and $\mathrm{Ni}$ with alkaline metals). The specific action of the aluminum takes place not only for $\mathrm{Ni}$, but and for other metals.

For color metals extraction from sediments formed after wastewater treatment, Covalev O., Covalev V., Duca Gh. [28] used the process, including the solubilization of metal compounds with $\mathrm{NH}_{4} \mathrm{Cl},\left(\mathrm{NH}_{4}\right)_{2} \mathrm{P}_{2} \mathrm{O}_{7}$ and ammonium hydroxide in the presence of magnetic fluidization. The mixture from $\mathrm{N}_{2} \mathrm{H}_{4} \cdot \mathrm{H}_{2} \mathrm{O}$ (hydrate of hydrazine), $\mathrm{HCOH}$ (formol) and $\mathrm{NaBH}_{4}$ (borohidrure of sodium) was used as a reducer. The advantage of such procedure consists in the possibility of simultaneous extraction of some metals by magnetic fluidization. The method necessitates using of some chemical substances for sediments solubilization and for metals reduction, some of them are toxic (ammonium), the others have high costs $\left(\mathrm{NaBH}_{4}\right)$. Another procedure proposed by Covalev O. and auth.[29] utilizes the sulfuric acid for the heavy metals extraction and its solubilization from waste water sediments, supplementary treatment with $\mathrm{SO}_{2}$ (gas) and the mixture of next reducers: hypophosfite of sodium and borohydrure of sodium in the rate of (5-10):1, as chemical agents for metal separation and application of high frequency current and magnetic fluidization. The quantity of chemical reagents in the comparison with the quantity of extracted heavy metals must be $(1,5-2,0): 1$, that exceeds those according to the stoechiometric coefficients of chemical reactions. The advantage of this method is the possibility of simultaneously extraction of some of metals from the formed sediments in galvanic waste water during the process of purification. The method is technologically 
advantageous, but it is difficult, because it is necessary to use the complicated modern installation, such as magnetic fluidization, installation with the high frequency currents, the generator for the $\mathrm{SO}_{2}$ generation, the purchase of it for most laboratories from the Republic isn't possible. These procedures propose some of chemical substances for sediments solubilization and for metal reduction, some of them are very toxic (ammonium) and others have high costs $\left(\mathrm{NaBH}_{4}\right)$.

Another procedure of purification of galvanic residual water [30] includes the treatment $\mathrm{RW}$ at $\mathrm{pH} 6 \ldots 8$ with reduction reagents in the following concentrations (M/l): lithium borhydride of sodium: 0,06...0,08; hypophosfite of sodium $0,26-0,30$; formic aldehide $0,60-0,70$; hydrasine $0,30-0,40$. This procedure utilizes the electromagnetic field (frequency of $60-74 \mathrm{kHz}$ ) and $\mathrm{Ni}-\mathrm{Zn}$ as a catalyzer in the rate of $1:(1,5-2)$. The advantage of the present procedure in comparison with those described in [28,29] consists in the possibility of waste water purification to a high grade. Only deficiency is the necessity to use a special equipment of the laboratory with different modern installations.

Stewart and auth. [31] have elaborated the procedure for consecutive iron and zinc extraction from acid galvanic solutions. For this, it is necessary the $\mathrm{NaOH}$ addition till a value of $\mathrm{pH} 5,4$. The sediment, which is formed, is separated by filtration at the $\mathrm{pH} 5,4$. Then the new quantity of $\mathrm{NaOH}$ is added till the value of $\mathrm{pH} 9,4$, and the sediment of $\mathrm{Zn}(\mathrm{OH})_{2}$ which is formed and is removed by filtration. The disadvantage of the procedures mentioned earlier is not only in the non qualitative galvanic waste water purification, but also in the impossibility of consecutive heavy metals extraction from galvanic solution, if more than 2 components are presented in solution.

The comparative analysis of procedures for galvanic waste water purification demonstrated that, the choice of one or another method depends on the chemical composition of waste water, and there doesn't exist a universal method for chemical purification of the galvanic waste. So, the galvanic waste from "Alfa» factory represents the fluid mass containing the mixture of $\mathrm{Cu}^{2+}, \mathrm{Fe}^{3+}, \mathrm{Al}^{3+}, \mathrm{Cr}^{3+}$ and $\mathrm{Zn}^{2+}$ ions, and for its valorification it was necessary to elaborate the method for metals separations and waste water purification.

\section{Waste Containing Vanadium}

As a result of the combustion of petrol products at Power Thermo electric Plant (PTP) the generation of some waste containing vanadium has happened the last decade. According to the statistical data recently received its quantity at PTP -1 is about 500 tons. It is necessary to be mentioned that these waste from the second class of toxicity present a risk for environment and people health. Its valorification will contribute to solve both important problems: waste liquidation and recuperation of about 18 tones of $\mathrm{V}_{2} \mathrm{O}_{5}$, with the total cost 17 millions lei.

There are different methods for extraction of vanadium from waste. According to Philippe G. [33] for vanadium recuperation from fly ashes (resulted after the petrol products combustion) the concentrated $\mathrm{NaOH}$ solution is used for vanadium selective solubilization. Vanadium separation was carried out by $\mathrm{CaO}$ addition in the quantity of 6-40 \% in comparison with the quantity of silica $\left(\mathrm{SiO}_{2}\right)$ included in ash.

For vanadium extraction from ashes of the coal combustion Kounhei Nimomya [34] has used the solubilization by $\mathrm{NaOH}$ at the $80-200^{\circ} \mathrm{C}$. The big part of vanadium and small quantity of calcium, iron and other metals are solved in the alkaline solution from which the vanadium is extracted by trioctilamine in an organic solvent at the $\mathrm{pH} 1-4$. The vanadium selective recuperation was carried out as a result of formation of a couple of vanadium ions with trioctilamine from the organic phase. Nickel from the resting solution has been precipitated with a selective oxime addition. Magnesium from resting solution was precipitated with an alkali.

The selective method of vanadium extraction from fly ashes is described by Musucava [35]. This method is proposed for the ashes solubilization in the relatively diluting alkaline solution at high temperature, with solution separation from the rest and solution treatment with the amine containing solvent for selective extraction of vanadium. Similar procedure is also proposed by Vaicutam L. and auth. [36]. According to Fassi and co-coath. [37], the vanadium waste is exposed to a thermal treatment at high temperature. The final product represents the second ores with the high $\mathrm{V}_{2} \mathrm{O}_{5}$ content. For vanadium extraction Bretschneider G. and Fritz [38] proposed the addition of a melt of carbonate and chloride of alkaline metals mixture to the material with vanadium contents in the presence of oxidizer with the following water solubilization and regulation of $\mathrm{pH}$ value up to 6,5 and addition of ammonium salt at the temperature $90^{\circ} \mathrm{C}$. After this process, solutions were cooled up to $15-20^{\circ} \mathrm{C}$ and the metavanadate of ammonium was precipitated in these conditions. At the temperature $300^{\circ} \mathrm{C}$ the decomposition of metavanadate of ammonium takes place with $\mathrm{V}_{2} \mathrm{O}_{5}$ obtaining.

For vanadium recuperation Goddard J[39] has proposed the method which consists in the frieding of vanadium containing waste with alkaline metal, following by the water solubilization. The vanadium extraction from the rest of combustion petrol products is carried out by the direct solubilization of the rest with $\mathrm{Na}_{2} \mathrm{CO}_{3}$ and $\mathrm{NaOH}$.

Other authors [40] use for the vanadium extraction a direct treatment of vanadium containing materials with alkaline reagents, sediment separation, its washing and collected soluble fractions were treated with ammonium compounds for metavanadate ammonium obtaining. The next step was effectuated similarly as in the case of Bretschneider G. and Fritz procedure.

There is another method for vanadium extraction - the sonic treatment with the frequency of 300-2000 kHz. Yoshimori Tadahico [41] used this method for vanadium and nickel extraction from the waste dispersed in water. Then 
the solution was filtrated for the ashes removing and obtaining of the vanadium solution. Haehn Reinhard and co-auth. [42] for facilitation of vanadium extraction process carry out the frieding of the mixture of vanadium containing the waste with additives (carbonates, chlorides, sulfates or nitrates) with the following solubilization of the mixture components. According to the work [43] the ashes are treated at $\mathrm{pH} 7-10$ in the presence of the carbonates, hidrocarbonates of alkaline metals or ammonium. The rest of carbon is separated from ashes, and it has been granulated for use as solid combustible.

According to the methods elaborated by some authors [44-46] vanadium separation from waste has been carried out by frieding of waste with carbonate or sulfate of alkaline metal and solubilization of vanadates. Haehn [47] proposes a method for frieding of initial waste without alkaline additives followed by the extraction (first step) and the second frieding after supplementation of additive to the solid rest and a second solubilization.

Besides the alkaline methods, there are the methods with acid solubilization of vanadium from waste, too (Mizin [48]. Vanadium waste with a high content of calcium has been pounded, then, it was treated with $\mathrm{H}_{2} \mathrm{SO}_{4}$ for $\mathrm{CaSO}_{4}$ formation, after the solution filtration $\mathrm{V}_{2} \mathrm{O}_{5}$ was obtained from the solution..

The method of Woolery M. şi Rigsby L. [49] forecast the treatment of ashes bitumen in the low acid medium, followed by the oxidation to $\mathrm{V}^{5+}$, at the temperature of $80-85^{\circ} \mathrm{C}$, precipitation of polyvanadates and its separation from nickel and magnesium that remain in the solution. $\mathrm{H}_{2} \mathrm{SO}_{4}$ solution for vanadium extraction has been employed by Corigliand [50], too. The acid solution after oxidation was treated with agents for chelating (for example, EDTA), followed by treatment with $\mathrm{NH}_{4} \mathrm{OH}$ for selective precipitation of polyvanadates of ammonium. The acid treatment is used by other authors [51]. $\mathrm{H}_{2} \mathrm{SO}_{4}$ has been injected in the mixture of ashes and water then hydrazine has been added as a reducer. At the beginning $\mathrm{pH}$ value in the mixture was2-3, then after supernatant separation and hydrazine supplementation at permanent stirring the value of $\mathrm{pH}$ was increasing to 5- 7 and the insoluble compound of vanadium has been separated by centrifugation. Kohlein [52] for vanadium extraction used solubilization following by gradual extraction of vanadium and nickel and its separation by ionic change chromatography. Vanadium is precipitated as a compound $-\mathrm{V}_{2} \mathrm{O}_{3}$

The analysis of a large spectrum of the articles in the field of vanadium valorification from different types of waste (ashes, residues, industrials waste from steel melt containing vanadium) present some essential phases of vanadium containing waste treatment

- The thermal pretreatment (frieding) with the additives (carbonates, chlorides, sulfates, nitrates), sonic treatment;

- The alkaline (with $\mathrm{NaOH}, \mathrm{KOH}$ ) or acid treatment (with $\mathrm{H}_{2} \mathrm{SO}_{4}$ ) for vanadium solubilization. The chemical treatment can be in the combination with oxidizer $\left(\mathrm{O}_{2}\right)$, or reducer $\left(\mathrm{SO}_{2}\right)$;

- Extraction by organic reagents in some of the cases.

- The vanadium precipitation from solutions by ammonium salts for obtaining of the $\mathrm{NH}_{4} \mathrm{VO}_{3}$ or polyvanadates;

- Thermal decomposition of $\mathrm{NH}_{4} \mathrm{VO}_{3}$ for $\mathrm{V}_{2} \mathrm{O}_{5}$ obtaining.

\section{Experimental part}

The experimental investigations have been carried out with the application of a performing apparatus. The waste probes and the substances obtained in experimental process have been analyzed with the utilization of atomic absorption spectroscopy (AAS), roentgeno fluorescent spectroscopy VRA - 30 (Carl-Zeiss, Germany), roentgeno-fluorometric BARS-3, thermo spectroanalyzer DERIVATOGRAF Q-1000, (firm MOM, Budapesta), oscilopolarograf ȚLA-03, fotocolorimeter FEK-2, potentiometer PM-10 (Germany). The analyses of hexacyanoferrate ions content in the washing water after hexacyanoferrate extraction were carried out by the Chişinău Sanitaro Epidemiologic Station

AAS was used for the determination of vanadium quantity in the residual water after the boiler washing at the TPT- 1 and of the content of heavy metals in the galvanic solutions after its separation.

The vanadium content after the extraction from TPT-1 waste by different extragents has been determined by photo colorimeter KFK-2. For experiments were used: a mixture from $20 \mathrm{~g}$ of the waste probe and $5 \mathrm{~g}\left(\mathrm{NH}_{4}\right)_{2} \mathrm{~S}_{2} \mathrm{O}_{8}, 100$ $\mathrm{ml} \mathrm{H}_{2} \mathrm{O}$ and $5 \mathrm{~g}$ of solid $\mathrm{NaOH}$ in the porcelain cups was treated at $100-140^{\circ} \mathrm{C}$ with a careful agitation. After cooling to the $20^{\circ} \mathrm{C}$, the mixture is solved in the bidistillate. The obtained solution was filtrated through a paper filter and the quantity was transferred in the $250 \mathrm{ml}$ retort. The vanadium content in solution was determined by the photo colorimetric method.

The total vanadium content in the dry vanadium waste from TPT-1 and the vanadium content resting in the waste after vanadium $(\mathrm{V})$ extraction by alkaline method $\left(12,5 \mathrm{~N} \mathrm{NaOH}\right.$ in the presence of $\left(\mathrm{NH}_{4}\right)_{2} \mathrm{~S}_{2} \mathrm{O}_{8}$ as the oxidizer) has been determined by roentgen-fluorescent spectroscopy method. The content of the metals, extracted together with vanadium by the alkaline method in the presence of oxidizer has been effectuated by the roentgen- fluorometric method.

All experiments were carried out by the use the bidistillate water. The acids solutions $\left(\mathrm{H}_{2} \mathrm{SO}_{4}, \mathrm{HNO}, \mathrm{HCl}\right)$ were the "chemical pure" qualifications. The salts $\left(\mathrm{ZnCl}_{2}, \mathrm{~K}_{2} \mathrm{Cr}_{2} \mathrm{O}_{7}, \mathrm{AlCl}_{3}\right)$ used for standard solutions were "chemical pure". 
For standards graphics of calibration in the case of roentgen-fluorometric (Bars-3) were used the following salts of metals with "analytic pure” and „chemical pure" qualification: $\mathrm{CaCO}_{3}, \mathrm{MnSO}_{4}, \mathrm{Cr}_{2}\left(\mathrm{SO}_{4}\right)_{3}, \mathrm{Co}\left(\mathrm{NO}_{3}\right)_{2}, \mathrm{NiSO}_{4}, \mathrm{ZnSO}_{4}, \mathrm{CuSO}_{4}$, $\mathrm{Fe}_{2}\left(\mathrm{SO}_{4}\right)_{3}$. Determination of the metals in the waste was carried out after vanadium extraction from dry sample.

\section{Hexacyanoferrate waste valorization}

In this work has been elaborated a new procedure for hexacyanoferrate waste neutralization (see scheme in fig. 2) [11]. The procedure is based on the hexacyanoferrate transformation in the soluble state by $\mathrm{CaO}$ or $\mathrm{Ca}(\mathrm{OH})_{2}$ addition, the separation of a soluble fraction by filtration and removing of the sediment (bentonite, levure fraction). The ions of $\left[\mathrm{Fe}(\mathrm{CN})_{6}\right]_{3}{ }^{4-}$ from solution are precipitated by soluble $\mathrm{Fe}(\mathrm{III})$ salt.

There are the next steps of the procedure:

1. Hexacyanoferrate waste is mixed with water up to $5 \%$ (volume), then the supplementation of $\mathrm{CaO}$, what interacts with $\mathrm{H}_{2} \mathrm{O}$ and (CAUTION !!!) exothermic reaction takes place with $\mathrm{Ca}(\mathrm{OH})_{2}$ formation. The fresh $\mathrm{Ca}(\mathrm{OH})_{2}$ is very active and contributes to solubilization of hexacyanoferrates, according to the reaction (5). The optimal hexacyanoferrates concentration is $5 \%$.

2. $\mathrm{Me}_{2}\left[\mathrm{Fe}(\mathrm{CN})_{6}\right]+2 \mathrm{Ca}(\mathrm{OH})_{2} \rightarrow 2 \mathrm{Me}(\mathrm{OH})_{2}+\mathrm{Ca}_{2}\left[\mathrm{Fe}(\mathrm{CN})_{6}\right]$

$$
\text { a. where } \mathrm{Me}-\text { ions } \mathrm{Cu}^{2+} \text { or } \mathrm{Fe}^{2+}
$$

3. Separation of aqua soluble hexacyanoferrate by decantation. There are bentonite and rest $\mathrm{of} \mathrm{Ca}(\mathrm{OH})_{2}$ and ferrocyanide in the solid phase. This sediment was washed with $\mathrm{H}_{2} \mathrm{O}$ for complete soluble hexacyanoferrate removing (till the negative reaction to cyanide test). The solid rest is removed to the site of disposal. The residual washing water is used in the closed cycle for dilution of initial vine waste (to concentration 5\%).

4. Addition of $\mathrm{HCl}$ solution to $\mathrm{Ca}_{2}\left[\mathrm{Fe}(\mathrm{CN})_{6}\right]$ solution (till $\mathrm{pH} 3-5$ ).

5. Sedimentation of ferrocyanide liquid phase by addition of soluble Fe(III) salt and formation of the insoluble $\mathrm{Fe}_{4}\left[\mathrm{Fe}(\mathrm{CN})_{6}\right]_{3}$, according to the reaction (6):

$$
4 \mathrm{FeCl}_{3}+3 \mathrm{Ca}_{2}\left[\mathrm{Fe}(\mathrm{CN})_{6}\right]=\mathrm{Fe}_{4}\left[\mathrm{Fe}(\mathrm{CN})_{6}\right]_{3} \downarrow+6 \mathrm{CaCl}_{2}
$$

6. Sediment removal by filtration and its dehidratation. The technology [11] has been used for neutralization of $1000 \mathrm{t}$ of hexacyanoferrate waste at the vine factory "Vismos".

\section{Galvanic waste valorization}

The elaborated new procedure for heavy metal extraction from galvanic waste has importance from both aspects: ecological and economical [17]. The ecologic aspect is to liquidate this type of waste which is dangerous for environment and economic - a possibility of essential quantitative recovery of metals is necessary for our national economy $(\mathrm{Cu}, \mathrm{Al}$, $\mathrm{Zn}$ and other metals).

The procedure proposed in this work includes the solubilization of partial liquid galvanic waste in solution of the concentrated solution of $\mathrm{H}_{2} \mathrm{SO}_{4}$ in the rate of $1: 1$, separation of the solution by decantation and the removing of the insoluble rest $\left(\mathrm{SiO}_{2}\right.$ and other solid particles).

The metallic iron (iron sawdust, generated as a waste in the process of detail fabrication) was used for $\mathrm{Cu}$ separation from galvanic residual solution by cementation method. This process was carried out by continued agitation at the temperature of $40-60^{\circ} \mathrm{C}$. The reduction of $\mathrm{Cu}^{2+}$ ions and $\mathrm{Cu}^{\circ}$ formation, according to the reaction (7):

$$
\mathrm{Cu}^{2+}+\mathrm{Fe}^{\circ}=\mathrm{Cu}^{\circ}+\mathrm{Fe}^{2+}
$$

Metallic copper is separated from the solution by filtration it was washed for 2-3 times with $\mathrm{H}_{2} \mathrm{O}$. This residual water is supplemented to the supernatant. $0,8-1,2 \mathrm{~cm}^{3}$ of $6 \mathrm{~N} \mathrm{HNO}_{3}$ are added to the solution after $\mathrm{Cu}$ separation and the solution is treated thermo for $2-3 \mathrm{~min}$. The complete oxidation of iron (II) in iron (III) takes place [32], according to the reaction (8):

$$
3 \mathrm{FeCl}_{2}+4 \mathrm{HNO}_{3} \rightarrow \mathrm{Fe}\left(\mathrm{NO}_{3}\right)_{3}+2 \mathrm{FeCl}_{3}+\mathrm{NO} \uparrow+2 \mathrm{H}_{2} \mathrm{O} \quad(\mathrm{pH}<1)
$$

In the obtained solution is added 4-8 N NaOH solution till the $\mathrm{pH}$ value 4,6-5,4. As a result, the $\mathrm{Fe}(\mathrm{OH})_{3}$ and $\mathrm{Al}(\mathrm{OH})_{3}$ hydroxides are formed and their co-precipitation takes place according to the reactions ( 9 and 10):

$$
\begin{array}{ll}
\mathrm{Fe}^{3+}+3 \mathrm{OH}^{-} \rightarrow \mathrm{Fe}(\mathrm{OH})_{3} \downarrow & (\mathrm{pH} 4,8-5,2) \\
\mathrm{Al}^{3+}+3 \mathrm{OH}^{-} \rightarrow \mathrm{Al}(\mathrm{OH})_{3} \downarrow & (\mathrm{pH} 4,8-5,2)
\end{array}
$$

The obtained mixture is separated through filtration. The filtrate is treated with $\mathrm{Na}_{2} \mathrm{SO}_{3}$ (for the $\mathrm{Cr}^{6+}$ reduction in $\mathrm{Cr}^{3}$ in the acid medium according to the reaction (11), and then with the $\mathrm{NaOH}$ to the $\mathrm{pH}$ value 7,8- 9,4, (is desirable $6,8-8,8)$, according to the reactions (12) and (13):

$$
\mathrm{H}_{2} \mathrm{Cr}_{2} \mathrm{O}_{7}+3 \mathrm{Na}_{2} \mathrm{SO}_{3}+6 \mathrm{HNO}_{3} \rightarrow \mathrm{Cr}_{2}\left(\mathrm{SO}_{4}\right)_{3}+4 \mathrm{H}_{2} \mathrm{O}+6 \mathrm{NaNO}_{3}
$$


Sedimentation with the $\mathrm{NaOH}: \quad \mathrm{Cr}^{3+}+3 \mathrm{OH}^{-} \rightarrow \mathrm{Cr}(\mathrm{OH})_{3} \downarrow(\mathrm{pH} 5,4-6,8)$

$$
\mathrm{Zn}^{2+}+2 \mathrm{OH}^{-} \rightarrow \mathrm{Zn}(\mathrm{OH})_{2} \downarrow
$$

As a result of the reactions in alkaline medium, $\mathrm{Zn}(\mathrm{OH})_{2}, \mathrm{Cr}(\mathrm{OH})_{3}$ and other components sedimentation takes place at these $\mathrm{pH}$ values. The sediments of $\mathrm{Cr}(\mathrm{OH})_{3}$ and $\mathrm{Zn}(\mathrm{OH})_{2}$ were separated by filtration. Then, the resting heavy metals were determined in the filtrate by atomic absorption spectroscopy method. The proposed technological scheme for consecutively heavy metals extraction is presented in fig. 3 [33].

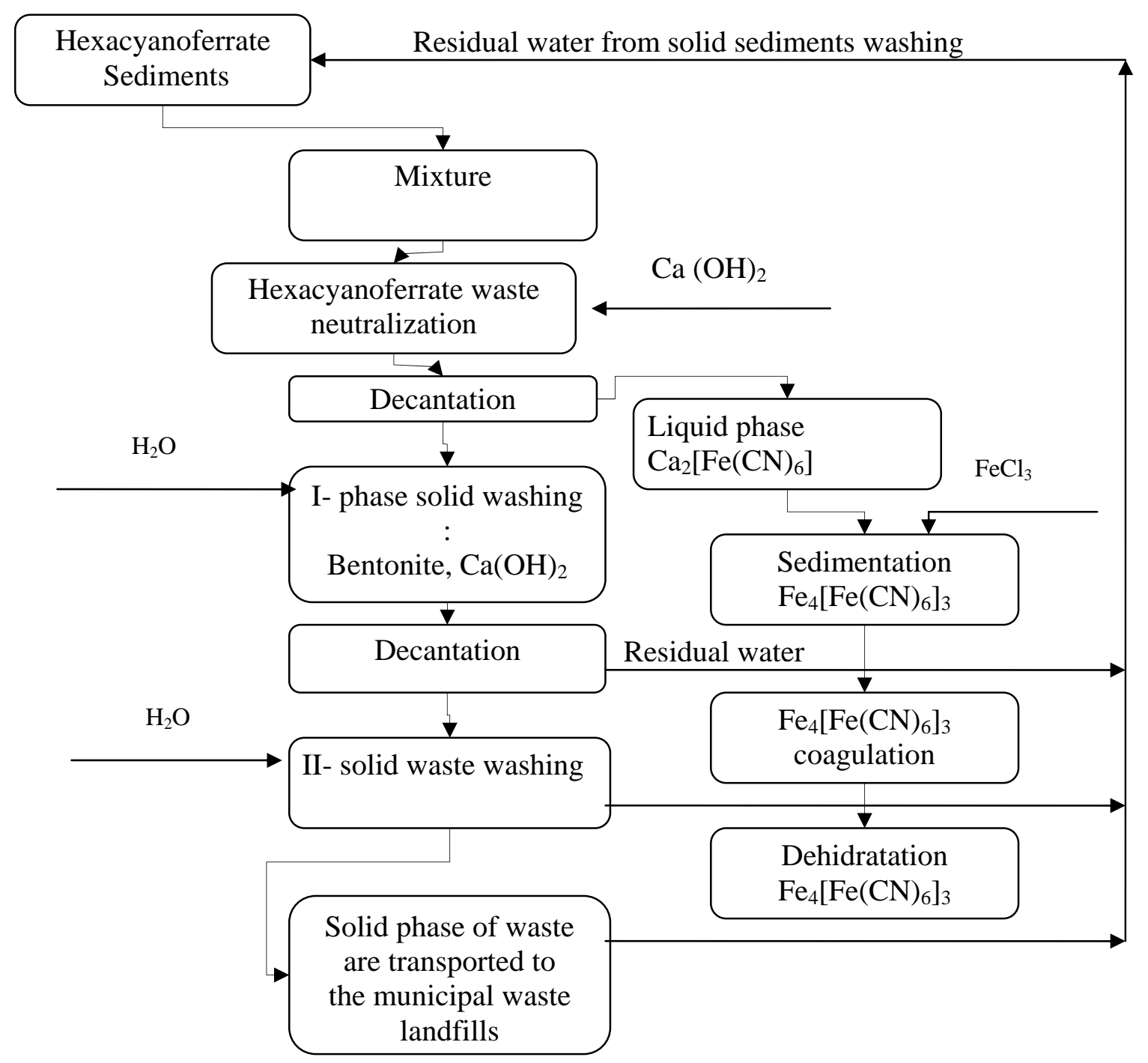

Fig. 2. Technological Scheme of hexacyanoferrate vine waste treatment

Thus, the procedure elaborated for heavy metals separation from waste water includes the next steps:

- the copper reduction by „,cementation” method when the metallic $\mathrm{Fe}$ is added in quantity of 5-10 times more than the stoechiometric quantity that is necessary for the copper substitution and its separation from waste water;

- the $\mathrm{Fe}(\mathrm{II})$ oxidation in the $\mathrm{Fe}(\mathrm{III})$ by $\mathrm{HNO}_{3}$, the addition of the alkaline solution and the heavy metals $\left(\mathrm{Fe}^{3+}\right.$ and $\mathrm{Al}^{3+}$ ) separation in the forms of hydroxides at the $\mathrm{pH} 4,8-5,4$;

- the separation of the sediments which were formed while iron and aluminum hydroxides and other components were mixed by filtration.

- the reduction of $\mathrm{Cr}(\mathrm{VI})$ in $\mathrm{Cr}(\mathrm{III})$ with $\mathrm{Na}_{2} \mathrm{SO}_{3}$ according to the reaction (11) and its sedimentation together with $\mathrm{Zn}^{2+}$ in form of hydroxides when $\mathrm{NaOH}$ is added;

- the separation of hydroxides $\mathrm{Cr}(\mathrm{OH})_{3}$ and $\mathrm{Zn}(\mathrm{OH})_{2}$.

The data (tab. 3) demonstrate that the proposed procedure permits the heavy metals removing from the residual galvanic water up to a high degree, so its content after purification don't exceed $0,5 \%$ from the initial quantity, excluding chromium ions. The rest of chromium content in the solution is $2,7 \%$. 


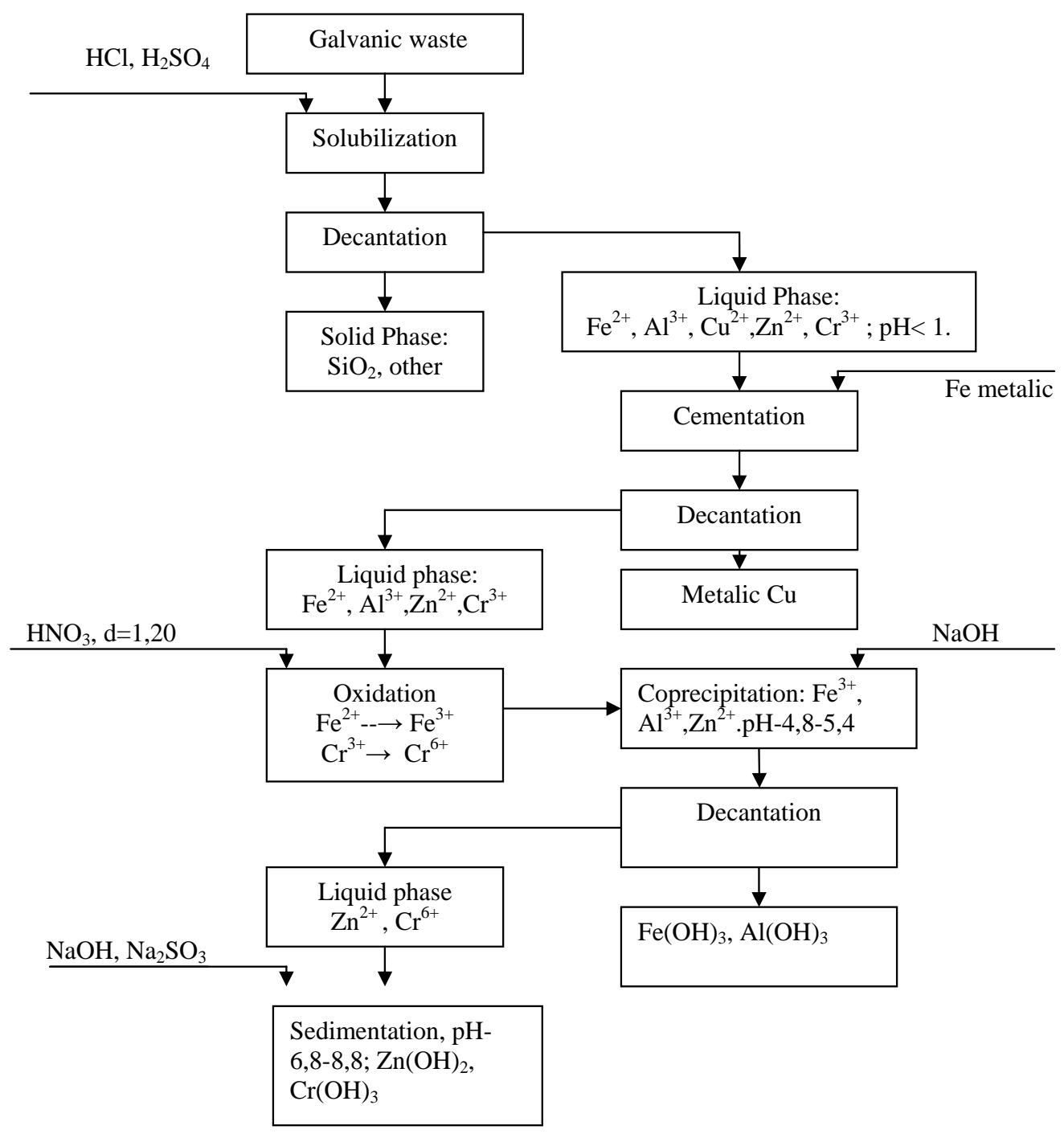

Fig. 3. Technological Scheme of Consecutive Separation of the Metals from Waste

The Content of Heavy Metals in Solution before and after Galvanic Residual Water Purification

\begin{tabular}{|c|c|c|c|c|}
\hline \multirow{2}{*}{ Metal } & \multicolumn{2}{|c|}{ Metals content in initial solution } & \multicolumn{2}{c|}{$\begin{array}{c}\text { Metals content in solution after metals } \\
\text { separation }\end{array}$} \\
\cline { 2 - 5 } & $(\mathrm{mg} / \mathrm{l})$ & $\%$ & $\mathrm{mg} / \mathrm{l}$ restant \\
\hline $\mathrm{Cu}^{2+}$ & 675 & 100 & 1,7 & 0,25 \\
\hline $\mathrm{Cr}^{3+}$ & 52,5 & 100 & 1,4 & 2,67 \\
\hline $\mathrm{Fe}^{3+}$ & 192,5 & 100 & 0,5 & 0,26 \\
\hline $\mathrm{Zn}^{2+}$ & 112,0 & 100 & 0,5 & 0,41 \\
\hline $\mathrm{Al}^{3+}$ & 96,0 & 100 & 0,4 & 0,42 \\
\hline
\end{tabular}

\section{Valorization of the Waste Containing Vanadium}

As a result of the comparison of methods for valorization of waste containing vanadium, we can conclude that the majority of them are used for valorization of waste with high vanadium content. Take into attention that the waste from the power thermoelectric station PTS-1(Chisinau) has a low content of vanadium $(\sim 3,0 \%)$, that why it is necessary to elaborate the new chemical technology for vanadium valorization from this waste.

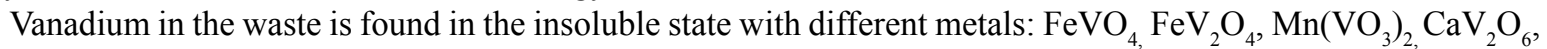
$\mathrm{CrVO}_{4}$. Vanadium extraction from these wastes can be carried out by alkaline and acid solubilization. The results of determination of optimal concentrations for extragents are demonstrated in table 4. 
Vanadium extraction from waste PTS-1

\begin{tabular}{|l|c|c|c|}
\hline \multirow{2}{*}{$\begin{array}{c}\text { Reagent } \\
\text { for extraction }\end{array}$} & \multicolumn{2}{c|}{$\begin{array}{c}\text { Content of vanadium extracted from } \\
\text { 20 g of waste }\end{array}$} & $\begin{array}{c}\text { \%, vanadium extraction from } \\
\text { the total vanadium in waste }\end{array}$ \\
\cline { 2 - 3 } & Mass $(\mathbf{g})$ & $1,2 \pm 0.06$ & $30,0 \pm 1,5$ \\
\hline $2 \mathrm{~N}$ solution $\mathrm{HCl}$ & $0,23 \pm 0,012$ & $1,2 \pm 0,06$ & $31,3 \pm 1,6$ \\
\hline $9 \%$ soluțion $\mathrm{H}_{2} \mathrm{SO}_{4}$ & $0,24 \pm 0,012$ & $2,8 \pm 0,14$ & $71,6 \pm 3,6$ \\
\hline $2 \mathrm{~N} \mathrm{solution} \mathrm{NaOH}_{2}$ & $0,55 \pm 0,028$ & $1,3 \pm 0,07$ & $32,8 \pm 1.6$ \\
\hline $\mathrm{HNO}_{3}$ conc. $+\left(\mathrm{NH}_{4}\right)_{2} \mathrm{~S}_{2} \mathrm{O}_{8}$ & $0,25 \pm 0,013$ & $3,7 \pm 0,19$ & $96,4 \pm 4,8$ \\
\hline $12,5 \mathrm{~N} \mathrm{NaOH}+\left(\mathrm{NH}_{4}\right)_{2} \mathrm{~S}_{2} \mathrm{O}_{8}$ & $0,74 \pm 0,037$ & & \\
\hline
\end{tabular}

The data from table 4 demonstrated that if the extragent is $\mathrm{NaOH}$ in the presence of $\left(\mathrm{NH}_{4}\right)_{2} \mathrm{~S}_{2} \mathrm{O}_{8}$ (as oxidizer) the extracted vanadium quantity from PTS-1 waste is of 3 times more than in the case of acid extraction [54].

As a result of experimental research of conditions and a screening of reagents for vanadium extraction from PTS-1 waste and application of the mathematic experimental planning (factorial experiment) $\mathrm{EFF}^{7-3}$ the optimal conditions were determined. These data have been used for elaboration of a technological procedure (fig. 4 ) of vanadium that is obtained from the waste containing vanadium.

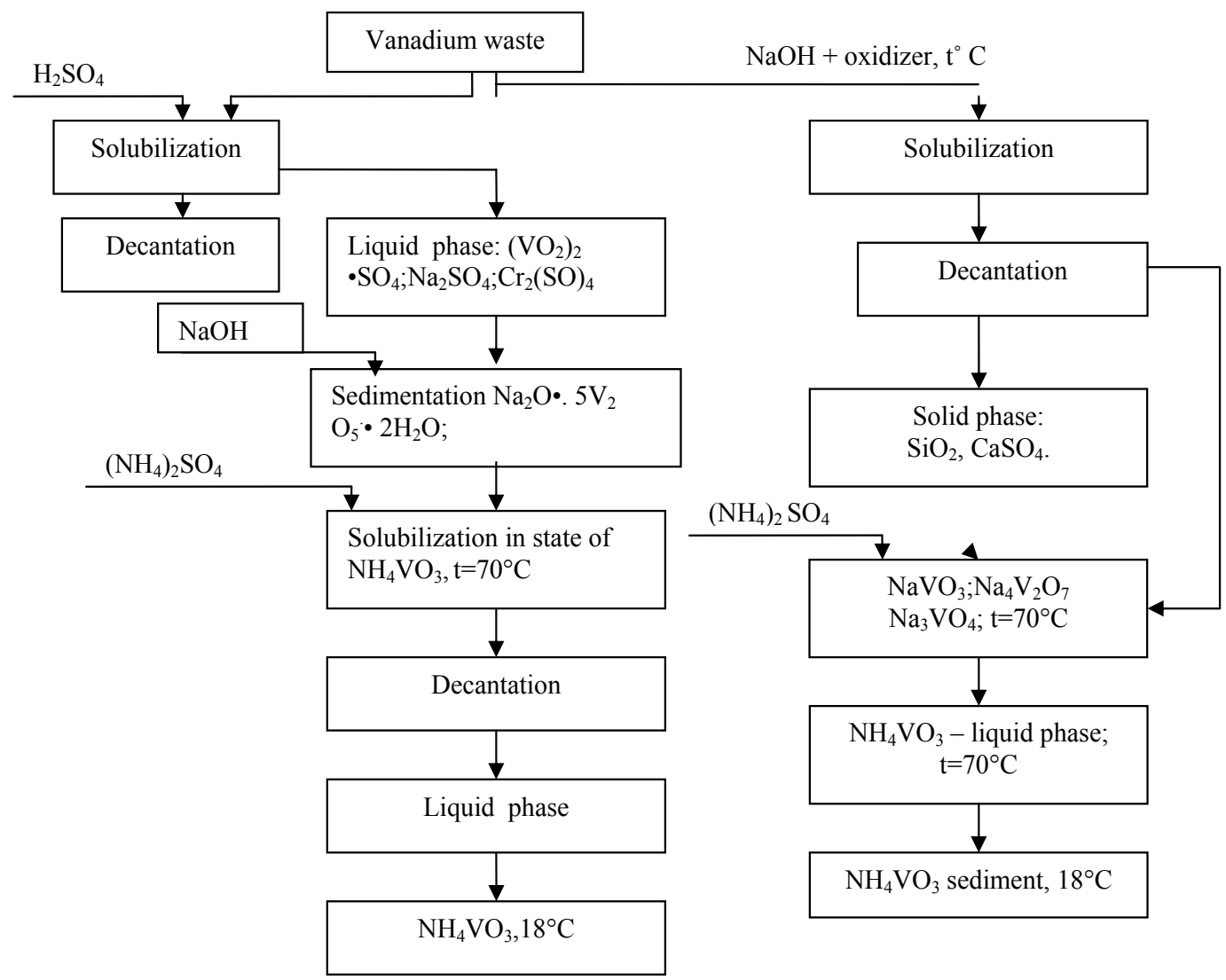

Fig. 4. Technological Scheme for Vanadium extraction from waste

There are the next steps for vanadium obtaining, according to the alkaline method:

- Vanadium extraction from the waste in diverse state of oxidation $\left(\mathrm{V}_{2} \mathrm{O}_{3}, \mathrm{~V}_{2} \mathrm{O}_{4}\right)$ (with $\mathrm{NaOH}$ in the presence of oxidizer $\left(\mathrm{NH}_{4}\right)_{2} \mathrm{~S}_{2} \mathrm{O}_{8}$ at the temperature about $120-140^{\circ} \mathrm{C}$ ) with obtaining of vanadium as: $\mathrm{NaVO}_{3}$ (metavanadate), $\mathrm{Na}_{4} \mathrm{~V}_{2} \mathrm{O}_{7}$ (pirovanadate) or $\mathrm{Na}_{3} \mathrm{VO}_{4}$ (ortovanadate) according to the reaction (14)

$\mathrm{V}_{2} \mathrm{O}_{3}+6 \mathrm{NaOH}+2\left(\mathrm{NH}_{4}\right)_{2} \mathrm{~S}_{2} \mathrm{O}_{8}=2 \mathrm{NaVO}_{3}+2\left(\mathrm{NH}_{4}\right)_{2} \mathrm{SO}_{4}+2 \mathrm{Na}_{2} \mathrm{SO}_{4}+3 \mathrm{H}_{2} \mathrm{O}$

- Filtration and treatment of the solution with $\left(\mathrm{NH}_{4}\right)_{2} \mathrm{SO}_{4}$ at temperature $70-90^{\circ} \mathrm{C}$ (during 1 hour) in the goal of transformation of the vanadium compounds in $\mathrm{NH}_{4} \mathrm{VO}_{3}$ according to the reaction(15):

$2 \mathrm{NaVO}_{3}+\left(\mathrm{NH}_{4}\right)_{2} \mathrm{SO}_{4}=2 \mathrm{NH}_{4} \mathrm{VO}_{3}+\mathrm{Na}_{2} \mathrm{SO}_{4}$

- $\mathrm{NH}_{4} \mathrm{VO}_{3}$ sedimentation at the temperature $18^{\circ} \mathrm{C}$. 
In the case of acid extraction with $\mathrm{H}_{2} \mathrm{SO}_{4}$ the vanadium is extracted as $\left(\mathrm{VO}_{2}\right)_{2} \mathrm{SO}_{4}$, which is transformed in $\mathrm{Na}_{2} \mathrm{O} \cdot 5 \mathrm{~V}_{2} \mathrm{O}_{5} \cdot 2 \mathrm{H}_{2} \mathrm{O}$ and then - in $\mathrm{NH}_{4} \mathrm{VO}_{3}$, according to the reactions (16), (17). The recovery of vanadium as $\mathrm{NH}_{4} \mathrm{VO}_{3}$ by this method is about $30 \%$.

$$
\begin{gathered}
\mathrm{Ca}\left(\mathrm{VO}_{3}\right)_{2}+2 \mathrm{H}_{2} \mathrm{SO}_{4}=\left(\mathrm{VO}_{2}\right)_{2} \mathrm{SO}_{4}+\mathrm{CaSO}_{4}+2 \mathrm{H}_{2} \mathrm{O} \\
\left(\mathrm{VO}_{2}\right)_{2} \mathrm{SO}_{4}+4 \mathrm{NaOH}=2 \mathrm{NaVO}_{3}+\mathrm{Na}_{2} \mathrm{SO}_{4}+2 \mathrm{H}_{2} \mathrm{O}
\end{gathered}
$$

The alkaline extraction in the presence of the oxidizer is more advantageous in comparison with the acid extraction, because the first method assures a high vanadium $\left(\mathrm{NH}_{4} \mathrm{VO}_{3}\right)$ recovery (about $94 \%$ from vanadium total content in the waste).

\section{Discussion}

As a result of our investigations for elaboration of some procedure of waste valofication by chemical methods, the optimal conditions of extraction have been established. Such, for chemical neutralization of the hexacyanoferrate waste the maximum concentration of waste in suspension didn't exceed 5\%. One of the conditions for quantitative solubilization of the hexacyanoferrate complexes is the reaction with the fresh $\mathrm{Ca}(\mathrm{OH})_{2}$ (that is obtained as a result of interaction $\mathrm{CaO}$ with $\mathrm{H}_{2} \mathrm{O}$ ) that is very active. Another condition for the high solubilization of hexacyanoferrate complexes is a careful agitation of the mixture.

After solid sediments separation (bentonite, rest of $\mathrm{Ca}(\mathrm{OH})_{2}$ and yeast) its careful washing by water for ions $\left[\mathrm{Fe}(\mathrm{CN})_{6}\right]^{4-}$ removing has been carried out up to the negative test at the presence of ions $\left[\mathrm{Fe}(\mathrm{CN})_{6}\right]^{4-}$. Washing residual water is used in the closed cycle for the dilution of a new portion of initial hexacyanoferrate waste.

The solution containing the $\left[\mathrm{Fe}(\mathrm{CN})_{6}\right]^{4-}$ ions is acidulated by $\mathrm{HCl}$ to the value of $\mathrm{pH} 3-5$ and then the sedimentation of ions $\left[\mathrm{Fe}(\mathrm{CN})_{6}\right]^{4-}$ is effectuated, according to the reaction (6). After $\mathrm{Fe}_{4}\left[\mathrm{Fe}(\mathrm{CN})_{6}\right]_{3}$ sedimentation this precipitation is dehydrated and in its dry form it can be used as pigment.

Another type of waste is galvanic waste. There are the following ions in its composition: $\mathrm{Cu}^{2+}, \mathrm{Fe}^{3+}, \mathrm{Al}^{3+}, \mathrm{Cr}^{3+}$ and $\mathrm{Zn}^{2+}$. Another waste is the iron sawdust that is used for copper removing from the acid solution, it is obtained after the galvanic waste solubilization. One of the conditions for this process is the careful magnetic agitation at the temperature of $40-60^{\circ} \mathrm{C}$. Another condition for $\mathrm{Cu}$ precipitation is the excess of the iron sawdust. The copper reduction by the cementation method at the metallic Fe addition in the quantity of 5-10 times more than the stoechiometric quantity is necessary for copper substitution and separation from waste water.

There is a mixture of $\mathrm{Fe}^{2+}$ and $\mathrm{Fe}^{3}$ in the solution after cooper removing. For sedimentation of these ions the solution of $6 \mathrm{~N} \mathrm{HNO}_{3}$ and thermic treatment for 3-4 min are used. As a result, all of iron ions are in the state of $\mathrm{Fe}^{3+}$. The qualitative removal of the $\mathrm{Fe}^{3+}$ and $\mathrm{Al}^{3+}$ is realized at the $6-8 \mathrm{~N} \mathrm{NaOH}$ addition, the temperature of $40-45^{\circ} \mathrm{C}$, at the magnetic agitation for a quantitative coagulation of $\mathrm{Fe}(\mathrm{OH})_{3}$ and $\mathrm{AL}(\mathrm{OH})_{3}$ mixture.

For $\mathrm{Cr}^{6+}$ removing it is necessary to provide a reduction of $\mathrm{Cr}^{6+}$ ions by $\mathrm{Na}_{2} \mathrm{SO}_{3}$, according to the reaction (11) at the constant agitation. The next step is the addition of $\mathrm{NaOH}$ solution up to the value of $\mathrm{pH} 5,4-6,8 \mathrm{for}^{\mathrm{Cr}}$ and $\mathrm{Zn}^{2+}$ co precipitation. Complete sedimentation of $\mathrm{Zn}(\mathrm{OH})_{2}$ takes place after increasing the $\mathrm{pH}$ value up to 8,8-9,0. The data (tab. 3 ) demonstrate, that the proposed procedure permits the heavy metals removing from the residual galvanic water up to a high degree, so the metals content after purification didn't exceed $0,5 \%$ from the initial quantity except chromium ions. The resting chromium content in the solution is $2,7 \%$. This fact can be explained by the partial chromium solubilization at the $\mathrm{pH}$ value that is necessary for sedimentation of hydroxides of chromium and zinc. It is worth mentioning that the content of analyzed solution in this work is more complex than in the other investigation [31] because of the supplementation of iron and zinc, galvanic waste including cooper, chromium and aluminum in the essential quantities. Consecutive separation of the metals was possible to carry out, as a result of the combination of method of cementation and chemical methods of separation with reagents. The elaborated procedure assures the qualitative galvanic residual water purification from heavy metals, this fact was confirmed by the low residual concentrations of metals in the residual water after purification [17].

The generation of PTS waste is a serious environmental problem for the Republic of Moldova and especially for Chisinau municipal. This fact has put the beginning for investigating the vanadium content and other components of these wastes with in the goal of its valorification. For vanadium extraction the diverse reagents solutions have been tested: $2 \mathrm{~N} \mathrm{HCl}, 9 \% \mathrm{H}_{2} \mathrm{SO}_{4}, 2 \mathrm{~N} \mathrm{NaOH}, \mathrm{HNO}_{3}$ conc. $+\left(\mathrm{NH}_{4}\right)_{2} \mathrm{~S}_{2} \mathrm{O}_{8}, 12,5 \mathrm{~N} \mathrm{NaOH}+\left(\mathrm{NH}_{4}\right)_{2} \mathrm{~S}_{2} \mathrm{O}_{8}$. The results of investigation demonstrate that a optimal vanadium quantity can be extracted in the latter case, that is with the $\mathrm{NaOH}$ solution and $\left(\mathrm{NH}_{4}\right)_{2} \mathrm{~S}_{2} \mathrm{O}_{8}$ (as an oxidizer). Another important condition is the temperature of extraction. There are three essential conditions for maximal vanadium extraction: $\mathrm{NaOH}$ concentration, utilization of $\left(\mathrm{NH}_{4}\right)_{2} \mathrm{~S}_{2} \mathrm{O}_{8}$ as an oxidizer, the optimal temperature regime $\left(90-140^{\circ} \mathrm{C}\right)$. The role of oxidizer is to transform all the form of vanadium in vanadium (V). The utilization of $30 \%$ of $\mathrm{NaOH}$ assures the solubilization of $\mathrm{V}_{2} \mathrm{O}_{5}$ and the formation of the $\mathrm{NaVO}_{3}$ [53]. 
After vanadium solubilization from waste, the next step is the reaction with some compounds of ammonium. This operation is realized between $\mathrm{NaVO}_{3}$ and $\left(\mathrm{NH}_{4}\right)_{2} \mathrm{SO}_{4}$ at $70-90{ }^{\circ} \mathrm{C}$ during 1 hour for $\mathrm{NH}_{4} \mathrm{VO}_{3}$ obtaining.

\section{Conclusions}

1. The technology of waste containing hexacyanoferrates has been elaborated and implemented - a contribution for reduction of an essential volume of such waste.

2. The technological scheme for galvanic waste treatment, that guarantees a high degree of residual water purification, has been founded theoretically and elaborated practically.

3. The chemical technology for valorification of waste from PTS and for vanadium obtaining $\left(\right.$ as $\mathrm{NH}_{4} \mathrm{VO}_{3}$ ) has been elaborated. It implementation will contribute to the reduction of the impact on environment and to an economical profit of about 17 millions lei.

Acknowledgements: Dr .Bounegru T. and professor Guțanu V. are acknowledged for their participation to the elaborated of hexcyanoferrate procedure neutralization and scientific col. Balaşa A. for participation to the elaborated procedure of vanadium extraction from waste

\section{References}

[1] Europe's Environment. The Dobříš Assessment. European Environment Agency, 1991, 676 p.

[2] Глобальная экологическая перспектива 2000. Доклад ЮНЕП о состоянии окружающей среды в конце тысячелетия, Интер Диалект, 2000, 398 с.

[3] Yakowitz, H. Waste management in Europe. Paper prezented at Global Conference, Strasbourg, 1992. OECD, Paris, $320 \mathrm{p}$.

[4] Okahoma, L. Environment Date Compendium. Organization for Economic Cooperation and Development, Paris, 1993, 240 p.

[5] Защита окружающей среды Европы: Третья оценка. Доклад по экологической оценки № $10,2003$. Европейское агенство по охране окружающей среды, 342 с.

[6] Badea, A., Apostol, T., Mărculescu, C. Aspecte ale strategiei României de gestiune a deşeurilor. Med. Înconj., 2003, no. 1, p. 25-37.

[7] Bulimaga, C. Deşeurile. Starea mediului în Republica Moldova în anul 2003, Chişinău, 2004, p. 83-88.

[8] Bulimaga, C. Deşeurile. Starea mediului în Republica Moldova în anul 2004, Chişinău, 2005, p. 88-95.

[9] Ghid ecologic pentru inspectorii de stat de mediu. Inspectoratul Ecologic de Stat Chişinău,2007, 257 p.

[10] Niderlandische Liste aus Verhandlung des Deutscen Bundestages 11, Wahlperiode 1987, Angalen Bd.397 (1990) „Sondergutachten Altlasten”des rates Von Sachverstandigen, fur Umweltfragen, Drucksache 11/6191, Seite 46 f. Tabelle 2.5 .

[11] Bounegru T., Guțanu V., Conunova Ț., Bulimaga C. Procedeu de neutralizare a deşeurilor obținute în urma demetalizării vinurilor cu hexacianoferat (II) de potasiu. Brevet de inv. MD, no. 923 din 28.02.98,. 1998, BOPI, no. 2.

[12] Bounegru T., Boțan V. Instalația de denocivizare a deşeurilor vinicole ce conțin albastru de Prusia (flux). Brevet de inv. MD, no. 2964, 2006, BOPI, no.1

[13] Bounegru T., Boțan V. Procedeu de neutralizare a deşeurilor vinicole ce conțin albastru de Prusia. Brevet de inv. MD, no. 2358, 2005, BOPI, no. 2

[14] Bounegru T., Boțan V. Instalația de denocivizare a deşeurilor vinicole ce conțin albastru de Prusia (ciclică). Brevet de inv. MD no. 2963, 2006, BOPI, no.1

[15] Bulimaga C. Studierea impactului întreprinderilor agroindustriale asupra mediului in Sesiunea XX de comunicări ştiințifice, Olăneşti-Vălcea, România, 1996, p. 1241-1244.

[16] Bulimaga, C. Unele aspecte privind conceptul managementului deşeurilor în Republica Moldova. Mediul ambiant. 2005, ed. sp. p.34-40.

[17] Bulimaga C. Procedeu de separare consecutivă a metalelor grele din apele reziduale. Brevet de inv. MD 2305 C2, Chişinău, 2003, BOPI, no.11

[18] Covaliov O., Covaliov V. Procedeu de dezactivare a precipitatului ce conține albastru de Berlin. Brevet de inv. MD, no.1981, 2002, BOPI no. 8

[19] Covaliov O., Covaliov V., Duca Gh., Reznic A., Barcari E. Procedeu de neutralizare a deşeurilor obținute ca rezultat al demetalizării vinurilor cu hexacianuferat (II) de potasiu. Brevet de inv. MD, no. 1618, 2001, BOPI no. 2

[20] Ковалев В., Ковалева О., Дука Г., Гаинэ Б. Основы процессов обезвреживания экологически вредных отходов виноделия. Кишинэу, 2007,343 с.

[21] France R., Kalnes T., Moser M. Method for treating streams containing undesired amounts of cyanides. Brevet 0572698 EPV MKI ${ }^{5}$ C 02 F I/72, 1993.

[22] Hadruc D., Trofin V., Anghel Gh. Procedeu de epurare a reziduurilor de la cleirea albastră a vinurilor. Brevet de inv. RO, no.113030, 1998. 
[23] Тананаев, И.Б., Сефер, Г.В.., Харитонов, Ю.Я. Химия фероцианидов. М. Наука, 1971, 320 с.

[24] Коган, Б.И. Современные методы очистки сточных вод от ионов тяжелых металлов. Обзорная информация. Серия Охрана окружающей среды. М., 1995, с.7-8.

[25] Мамонтова А.А., Рода И.Г., Топкин Ю.В. Способ очистки хромсодержащих сточных вод. Патент СССР №1786519б б МКИ5 СО2 F1/62//. 1992.

[26] Щеглюк М., Р., Щеглюк А.,И., Боярина Ж.,А.. Способ обработки сточных вод содержащих ионов тяжелых металлов. Патент СССР №182930,9 А1 С02 F 1/62. 1989.

[27] Будиловски, Ю.Я., Рыскин, С.,Я., Сланкснене, Д.Э. Способ очистки сточных вод от ионов тяжелых металлов. Авт. свид. СССР 778181, 1989.

[28] Covalev O., Covalev V., Duca Gh. Procedeu de extragere a metalelor neferoase din sedimentele apelor reziduale. Brevet de inv. MD, no.1173 F C 02 F 11/14, 1999 BOPI no.3

[29] Covaliov V.,Covaliova O., Duca Gh. Procesul de purificare a apelor reziduale de ionii metalelor grele. Brevet de inv. MD 1649, C 02 F 1/62, 2001, BOPI no. 4

[30] Covaliova O., Covaliov V., Pelinețchi C., Ivanov E. Proces de extragere a metalelor grele din precipitatele apelor reziduale. Brevet de inv. MD 488, 1996, BOPI, no. 3.

[31] Stewart G. Chan G. Sequiential separation of metals by controlled pH precipitation. US Patent 5128047, MKU5 CO2,1992.

[32] Алексеев, В.Н. Курс качественного химического полумикроанализа. М,1962, 311 с.

[33] Philippe G. Process for treatment of vanadium containing fly ash. Patent US 3873669 CO1G3 1/00, 1975.

[34] Kounhei Nimomya. Process for vanadium separation. Patent JP 60071527 CO1G31/00, 1985.

[35] Mutsucawa, Nobuaki. Method for recovering valuable metal of vanadium, nickel and magnezium from petroleum combustion ash leach liquor containing them. Patent JP 2001262242 C22Bt/02, 2001.

[36] Vaicutam, L., Dzinsars, M., Geisler, R. Process for treatment of fly ash. Patent US 4798709 C22b7/02, 1989.

[37] Fassi S., Mendelsohn N. Processes for upgrading industrial Wastes. Patent Fr. 2625512 C04B 5/02, 1989

[38] Gunter B., Fritz S. Process for solubilising vanadium values. Patent US 3300276, 1967

[39] Goddard J. Alkaline leaching of vanadium bearing residues. Patent US, 4640823 CO 1G31/00, 1987

[40] Лудрявский Ю.Р., Стрелков В.В., Трапезников Ю. Способ получения пятиокиси ванадия. Патент Россия №2178468 C1 C22B34/22, 2002.

[41] Yoshimori, T. Separation of vanadium and/or nickel from ash containing carbon. Patent JP no.60186419 C01G31/00, 1985.

[42] Haehn R., Sattelberger S., Fichte R.F,. Process for extraction of vanadium from vanadium containing raw materials. Patent DE 3536495 C22B34/22, 1987.

[43] Acahori, A. Method for recovering vanadium from combustion ash. Patent JP 63040726 CO1G31/02, 1998.

[44] Mccorriston L. Process using carbonate reagent for recovering vanadium from cokes and ashes derived from heavy oils. Patent US 4536374 C01G31/00, 1985.

[45] Mccorriston L. Process using alcaline reagent for recovering vanadium from cokes and ashes derived from heavy oils. / Patent US 4472360 C01G31/00, 1984.

[46] Mccorriston L. Process using sulfate reagent for recovering vanadium from cokes derived from heavy oils. Patent US 4389378 C01 G31/00, 1983.

[47] Haehn R, Sattelberger S., Fichte R. Method of recovering vanadium from vanadium containing materials with at least $6 \mathrm{wt} \%$ oxide vanadium compounds. Patent US 4748009 C22 B34/22, 1988.

[48] Мизин В.Г., Сирина Т.П., Добош В.Г., Комратов Ю.С. Способ переработки высококальциевых ванадийсодержащих материалов. Патент Россия №2147620, C01G31/02, М., 2000.

[49] Woolery M., Rigsby L. Separation and recovery of metal values from natural bitum ash . Patent EP 0616039 C22B34/22, 1994.

[50] Corigliand F., Pasquale S., Primerano P., Zipelli C. Method for recovering vanadium from rezydues from combustion of petroleum fractions. Patent US 4788044 CO1B17/90B, 1988.

[51] Negoro M, Kita Y., Tokunaga S, et al. Method for recovering vanadium from petroleum incineration ash. Patent JP 8325651 C22B34/22, 1996.

[52] Kohlein J, Neugebauer A, Olbrich R. Process for the selective separation of the metals from vanadium/nichelsalt solutions. Patent AT 404258B C22B3/26, 1998.

[53] Bulimaga C., Balaşa A. Procedeu de extragere a vanadiului din reziduurile provenite din arderea păcurii. Brevet de inv. MD 3148 G2, 2006 BOPI nr. 9

[54] Kareakin J.V., Angelov I.I. Cistâe himicescie veşcestva., M., Izd-vo „Himia”, 1974.407 c. 